\title{
PENSION PAYMENT AS A CRITICAL INFRASTRUCTURE
}

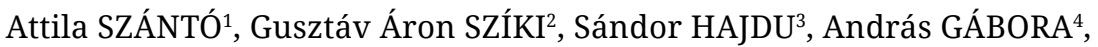 \\ Kristóf Balázs SIPOS ${ }^{5}$ \\ University of Debrecen, Faculty of Engineering, Department of Mechanical Engineering, Debrecen, Hungary \\ ${ }^{1}$ szanto.attila93@gmail.com \\ ${ }^{2}$ szikig@eng.unideb.hu \\ ${ }^{3}$ hajdusandor@eng.unideb.hu \\ ${ }^{4}$ andrasgabora@eng.unideb.hu \\ ${ }^{5}$ siposk94@gmail.com
}

\begin{abstract}
In the following the role and contribution of vehicle dynamics simulation to the development of race cars at the Faculty of Engineering of the University of Debrecen is presented. The application of the developed simulation program for the optimization of the car's technical data, together with the principle and method of optimization, is also described here.
\end{abstract}

Keywords: dynamics modelling, simulation, optimization, MATLAB.

\section{Introduction}

The Faculty of Engineering, University of Debrecen has a long experience in the design, development and construction of vehicles with alternative drive [1, 2, 3]. In the last few years the students at the our faculty have designed and constructed several race cars with alternative (electric or pneumatic) drive and have taken part and achieved successes in domestic and international competitions [4, 5]. In the MVM Race in 2014 and 2015 the race car that was developed by the Department of Mechanical Engineering scored first and second place respectively. In the case of the competition "Shell ECO Marathon" - organized in London in 2016 and 2017 - we have also taken part and performed it successfully. For more effective racing we have developed a simulation program [7] in Matlab [6] environment, which is capable of calculating the vehicle dynamic functions of the car from its technical data. The above data have to be measured or sometimes can be found in the literature. $[8,9,10]$ By now it has become a prerequisite of successful racing, since from the big number of possible values of technical data we can select the optimal ones by simply applying the above program.

\section{Description of the optimization method}

In motorsport it is crucial to choose the technical data (setting) of a vehicle correctly, because a vehicle's construction is competitive only if its' technical data are optimized for a race situation. We can realize this with an optimization process.

We can apply our simulation program [11] to optimize [12] the technical data of a vehicle in two different ways: in the first case, for designing a new vehicle. In this situation only a few vehicle parameter values are fixed (for example defined by the competition rules), so we can optimize the other parameters for the competition problem. So, based on the simulation results, we can design the best race car for the competition (e.g. 400 $\mathrm{m}$ drag race). The second case is when our aim is to prepare an existing race car for a competition. In this case we can modify significantly less of technical parameter values, but applying the simulation program and optimization process we can save a lot of time and reduce the costs significantly.

In order to optimize the vehicle's technical data, we used our simulation program, complemented by another program [11] written in the Matlab environment. The essence of the process is that 
we change the value of one or more of the parameters in the simulation program systematically, and we evaluate the obtained results of the multiple running of simulation and determine the optimal values of technical data for the race.

If we intend to vary one or two technical parameters only, we have the opportunity to write a Matlab program [11], which first defines the parameters to be tested, then runs the simulation program with the different values of the parameters. After that it records that parameter (e.g. gear ratio) values among the results which belong to the desired target value (e.g. time to reach 40 $\mathrm{km} / \mathrm{h}$ ). If, these are presented on a graph, we can find the optimal value. (An example is the Figure 1.)

In the case of a multiple variable problem, we cannot present the obtained function in two or three dimensions, thus we cannot read the optimum values directly. In this case we have to apply the Simulated Annealing Method in the Global Optimization Toolbox within Matlab. Also in the case of one and two variables the application of the above toolbox is more practical than the previous method. The operating principle of this method is that the program identifies the optimum in a specific parameter space (e.g. minimum of a function). The parameter space can be a function, or if it is not available, the set of points obtained by running the simulation with different parameter values. Optimum search is performed by starting from a given point (this point can be optionally specified), the program examines the value of the next point with certain size jumps (this is the "cooling speed") and compares it with the current value. Repeatedly applying the above method, the program crawls the parameter space data in different coordinate directions. The program will continue to move in that direction where the values are decreasing: the optimum direction. In order to not stick at a local minimum location, occasionally, the program examines one of the points away from the current one. If the program finds a lower value in that area, then it continues the detailed search at this place. The "cooling speed" specifies the distance between the current examined point and the next point. This will gradually decrease during the running of the program. Thus, the step size decreases while approaching the optimum value. In our actual case, a specif-

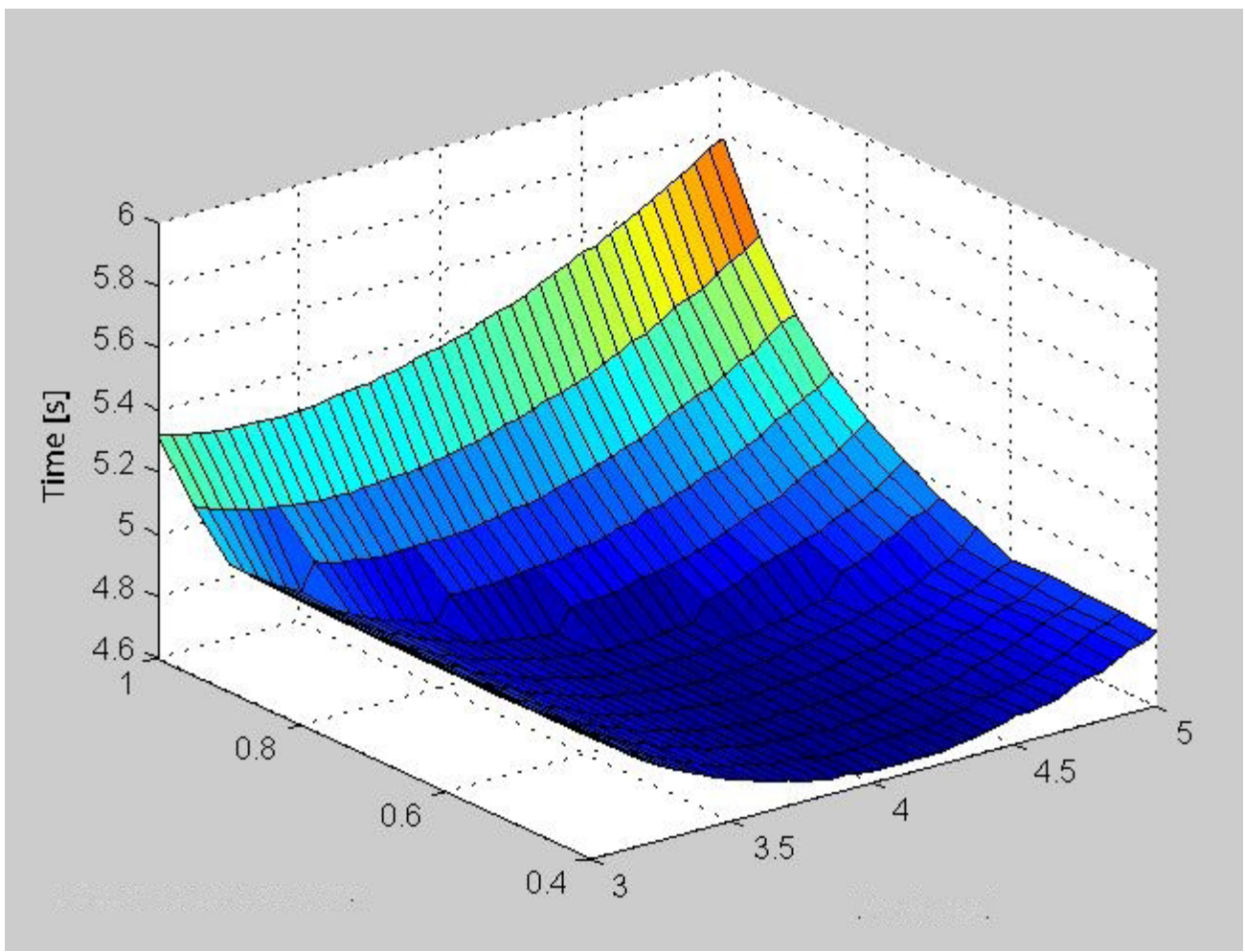

Figure 1. Time required to reach $40 \mathrm{~km} / \mathrm{h}$ as a function of gear ratio in the chain drive and position of the centre of gravity of the vehicle 
ic function is not available, therefore, instead of a function, the points obtained from the runs of the simulation program with different parameter values are given for optimization. To create this function we need to do a Matlab function [12]. (As an example, the goal is to reach $40 \mathrm{~km} / \mathrm{h}$ in the shortest time, and the variable parameter will be considered i12 chain gear.)

The function calls the simulation with the i_g (= i12) transmission value in the parameter field and returns the time needed to reach the $40 \mathrm{~km} / \mathrm{h}$ speed value. Then the optimization program compares these time values, identifying for the smallest one.

The program finds the optimum gear ratio after approximately 1500 iterations. This means that the simulation is executed 1500 times with different values of chain gears. If we stop the running, then the program will print the best time value and the corresponding optimal transmission value in the Matlab Command Window (Figure 2.).

This procedure can be used for several variables to optimize for different competition problems (e.g. drag race or power efficiency competition).

Detailed description of the optimization can be found in [12].

\section{Summary}

To be able to perform the optimization we had to restructure our simulation program first, and then choose the proper optimization method and write the optimization programs in Matlab. Finally, we applied the optimization program for the calculation of the optimal technical data of the race cars. The optimization method works properly, so we can apply the program for the design of newly developed cars. Nevertheless, the simulation program has small deficiencies. One of these is that we cannot perform real time simulation. We are planning to develop a real time simulation program for the whole vehicle and also a graphical interpretation of the above program showing the vehicle on the racetrack and also the instantaneous values of vehicle dynamic parameters. This way the technical data of the vehicle could be optimized for the whole race.

\section{Acknowledgments}

Supported BY the ÚNKP-17-2 New National Excellence Program of the Ministry of Human Capacities

\section{References}

[1] Zöldy M., Emőd I., Tölgyesi Z.: Alternatív jármühajtások. Maróti Könyvkereskedés és Könyvkiadó Kft., 2006

[2] Juhász György: A pneumobil versenyek és az oktatás - a felkészülés tanári szemmel. Debreceni müszaki közlemények 10/1. (2011) 35-40.

[3] Gábora A., Szíki G. Á., Szántó A., Varga T. A., Magyari A., Balázs D.: Prototype battery electric car development for Shell-ECO-Marathon ${ }^{\circledR}$ competition. In: Proceedings of the $22^{\text {th }}$ international scientific conference of youngth engineers, Cluj, Kolozsvár, Romania, Müszaki Tudományos Közlemények 7. (2017) 167-170.

https://eda.eme.ro/handle/10598/29772

[4] Shell-ECO-Marathon ${ }^{\circledR}$ verseny:

http://www.shell.com/energy-and-innovation/ shell-ecomarathon.html (accessed: 2017. 11. 20.)

[5] Aventics pneumobil verseny In: http://www.pneumobil.hu (accessed: 2017.11. 20).

[6] Matlab 2014b, The MathWorks, Inc, Natick, Massachusetts, United States.

[7] Szántó A.: Elektromos hajtású tanszéki versenyautó jármüdinamikai modellezése, TDK dolgozat (2015), Debreceni Egyetem Műszaki Kar.

[8] Pacejka H. B., Besselink I.: Tire and Vehicle Dynamics (Third edition), Elsevier Ltd. 2012.

[9] Reimpell J., Betzler J. W., Bári G., Hankovszki Z., Kádár L., Lévai Z., Nagyszokolyai I.: Gépjármüfutómüvek I., Typotex, 2012.

[10] Heissing B., Ersoy M.: Chassic Handbook - Fundamentals, Driving Dynamics, Components, Mechatronics, Perspectives, Springer, 2011.

\section{Command Window}

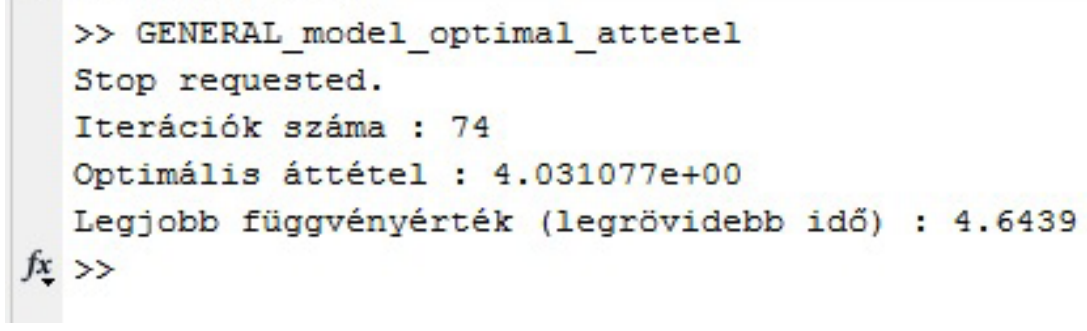

Figure 2. The results obtained after interruption of the run 
[11] Szántó A.: Járműdinamikai szimuláció és optimalizáció Matlab és LabVIEW környezetben, TDK thezis, University of Debrecen, 2017.

[12] Erdősné Sélley Cs., Gyurecz Gy., Janik J., Körtélyesi G.: Mérnöki optimalizáció, Typotex kiadó, 2012. 